PLANTS PEOPLE

POSSIBILITIES

Cascara Sagrada. (Rhamnus Purshiana, DC.)

Author(s): W. J. Bean

Source: Bulletin of Miscellaneous Information (Royal Botanic Gardens, Kew), Vol. 1913, No. 3 (1913), pp. 123-125

Published by: Springer on behalf of Royal Botanic Gardens, Kew

Stable URL: http://www.jstor.org/stable/4115097

Accessed: 27-06-2016 02:32 UTC

Your use of the JSTOR archive indicates your acceptance of the Terms \& Conditions of Use, available at

http://about.jstor.org/terms

JSTOR is a not-for-profit service that helps scholars, researchers, and students discover, use, and build upon a wide range of content in a trusted digital archive. We use information technology and tools to increase productivity and facilitate new forms of scholarship. For more information about JSTOR, please contact support@jstor.org.

\footnotetext{
Royal Botanic Gardens, Kew, Springer are collaborating with JSTOR to digitize, preserve and extend access to Bulletin of Miscellaneous Information (Royal Botanic Gardens, Kew)
} 
angulis crenatis. Folia rudimentaria $1 \mathrm{~mm}$. longa, deltoidea, acuta, decidua. Spini solitarii, a pice stellato-ramosi vel simplices, $8-17 \mathrm{~mm}$. longi, 1.5-2 mm. crassi, glabri, cinerei. Pedunculi erecti, 7-12 mm. longi, $1-2.5 \mathrm{~mm}$. crassi, umbellatim 2-6-flori vel interdum uniflori, minute bracteati. Pedicelli 5-6 mm. longi, apice bibracteati. Bracteae 2-3 $\mathrm{mm}$. longae et latae, subquadratae, apiculatae, glabrae. Involucrum 5-6 mm. diametro, late campanulatum, glabrum, viride, glandulis 5 transverse ellipticis vel sub-reniformibus integris atroviridibus. Ovarium non vidi.

South Africa. Ladismith Div.: near Doornkloof River, between Muis Kraal and Ladismith, N. S. Pillans.

The description and figure of this species are made from a living plant sent by Mr. Neville S. Pillans to the Royal Botanic Gardens, Kew, where it flowered in Dec., 1912. E. Pillansii is allied to $E$. stellaespina, Haw., but is well distinguished from that species by its much fewer angles, stouter spines, and the transverse pale greenish bars upon its stems. The figure represents the plant of its natural size.

\section{XVIII.-CASCARA SAGRADA.}

\section{(Rhamnus Purshiana, DC.)}

\section{W. J. Bean.}

Attention has already been called in these pages to the possibility of this drug proving a remunerative culture in the British Isles (see $K . B .1908$ p. 429) and the question has aroused considerable interest in various parts of the country. In 1908, seeds of Rhamnus Purshiana were distributed from Kew to about twenty establishments in England, Scotland and Ireland. Reports have just been received from most of the recipients as to the germination of the seeds, also notes on the behaviour of the plants. The seeds as received from America do not appear to have had a high germinating power, and even the most successful results do not show that more than 35 per cent. were fertile. The seeds appear to have germinated best when the stiff pulp (the dried fruit) in which the seeds, as received, are embedded is removed before sowing. The most successful results both as to germination and growth have been obtained in the garden of Mr. Collis-Sandes at Oak Park, Tralee, Ireland, where some of the plants raised from the 1908 seed are already 9 feet high, 8 feet in diameter, and 6 inches in girth of stem. At Fota they are 7 feet, at Rossdohan 8 feet, and at Glasnevin 6 feet high. The tree is also succeeding particularly well in the south-west of Scotland with Sir Herbert Maxwell, who had six plants from Kew in 1908. Plants at the Edinburgh Botanic Garden are thriving well.

The species, like our native $\boldsymbol{R}$. Frangula, is capable, evidently, of very soon arriving at the fruiting stage, for Sir Herbert Maxwell's plants bore a plentiful crop of berries in 1911, and although his plants are two or three years older than the plants raised from seed in 1908, they show that, in favourable circumstances, trees five or six years old will produce fruit. It appears 
probable, therefore, that once the tree becomes established its propagation will offer no difficulties. It is pretty certain that seeds sown directly from the tree will give a higher percentage of germination than those that have been kept an indefinite time in seed-rooms. Sir Herbert Maxwell did not save his seed, but that gathered from older trees at Kew has germinated well.

This Rhamnus seems to prefer a light to a heavy soil, and wherever it has been tested, has made the best growth in the former. In the cold district of Aldenham House, Elstree, Herts, Mr. Vicary Gibbs reports that the plants raised from the 1908 seed, although very healthy, are only 2 feet high planted in heavy soil ; and at Woburn, Mr. Spencer Pickering reports that in a light soil the plants have done much better than in a heavy one, some of last year's growths in the former being 3 feet long. At Colesborne, in Gloucestershire a cold limestone district, Mr. H. J. Elwes informs us that the 1908 plants are quite hardy and healthy, but grow slowly-about 2 feet only in three years.

Of the hardiness of the species in the greater part of the British Isles, there is, we believe, no doubt. At Kew, the trees raised from seed in 1891 withstood the great frosts of February, 1895, without being in the least affected, although the minimum temperature for a few nights ranged between $1^{\circ}$ and $6^{\circ}$ Fahr.

In connection with the possibility of establishing plantations of $\boldsymbol{R}$. Purshiana, attention may again be called to the fact that it has been found possible at Kew to strike cuttings by taking them in July. The cuttings should be of the new shoots 3-4 inches long with a "heel" of older wood at the base (see $K . B ., 1912$, p. 393).

As already indicated in the Kevv Bulletin (1908, p. 429), the bark collected from the trees at $\mathrm{Kew}$ has been shown to possess medicinal properties indistinguishable from those of American Cascara. It has been suggested to us that it by no means follows that the bark of trees grown in the damp, less sunny parts of the British Isles will be equal in quality to the Kew product-the Thames Valley being one of the sunniest and driest districts in the Kingdom. This, of course, is a matter for experiment.

At the prices at present obtainable for Cascara Sagrada, it scarcely seems likely that it would prove a paying crop. In Bulletin No. 139, p. 40, issued by the Bureau of Plant Industry, United States Department of Agriculture, it is stated that one tree is estimated to yield approximately $10 \mathrm{lbs}$. of bark. As the price then (in 1908) paid to collectors for the bark was 3 to $4 \frac{1}{2}$ cents. per lb., it follows that the produce of one tree barely amounted to two shillings. At this price the cultivation of the tree cannot be remunerative, especially if a system of collecting the bark is adopted (as in America) that proves fatal to the tree.

The bark of the tree grown at Kew proved very difficult to remove, and had to be scraped or cut off rather than peeled, but this was done in February. The collecting season in America, which opens about the end of May or early in June and closes about the end of August, covers the period of the greatest flow of sap. The bark evidently comes away easily enough then, as it is brought to market in "quills" or rolls. 
Another factor to be taken into consideration is that Cascara bark should be at least one year gathered before it is used.

There is every probability that the price of this drug will rise considerably. In 1908 the world's consumption was said to be two millions of pounds annually, which means that 200,000 trees would have to be destroyed yearly to maintain the supply. As no steps are being taken in America to renew the trees, it is evident that the natural supplies must fail within a limited time. As Cascara Sagrada is a most valuable laxative with unique properties, it appears likely that the demand for it would continue with greatly enhanced prices.

An interesting question is whether some means of utilising the younger parts of the tree, say the one- or two-year-old shoots, can be devised, which would leave the tree as a whole uninjured. The year-old bark is said to be equal in medicinal value to that on older wood, and if the tree were grown in plantations whence an annual crop of branchlets could be taken, its cultivation and utilisation would be much simplified and cheapened.

\section{XIX.-MISCELLANEOUS NOTES.}

Mr. A. H. KIRBY, B.A., Scientific Assistant, Imperial Department of Agriculture for the West Indies, has been appointed by the Secretary of State for the Colonies, Assistant Director of Agriculture in Southern Nigeria.

Mr. F. W. Soutr, B.A., Mycologist and Agricultural Lecturer, Imperial Department of Agriculture for the West Indies, has been appointed by the Secretary of State for the Colonies, Chief Agricultural Inspector, Federated Malay States.

Mr. T. D, Maitland, Curator in the Agricultural Department, Southern Nigeria $(K . B .1910$, p. 64$)$, has been appointed by the Secretary of State for the Colonies a District Agricultural Officer in the Uganda Protectorate.

Larix occidentalis.-It may be of interest to put on record for future reference the making of a plantation of this larch in the grounds of Queen's Cottage at Kew. In February, 1909, a parcel of seed was presented to Kew by Mr. A. Henry. The seeds germinated well, and about 600 plants were raised in the Arboretum nursery. Having reached a size at which it became necessary to find permanent quarters for them, it was decided to make a plantation in the Queen's Cottage Grounds, where one of the clumps of miscellaneous trees was cleared away for the purpose. Some 400 trees were put out on March 12th and 13th, 1913, on a piece of ground one-third of an acre in extent, which enabled the young trees to be set out about 6 feet apart. Except for a liability to be injured by late spring frosts, which causes a number of "leaders" to form instead of one, these young larches are succeeding well at 